OECD Development Co-operation Working Papers No. 15

Food and Nutrition

(in-)Security and Social

Protection
Rachel Slater,

Rebecca Holmes,

Nicholas Mathers 


\section{Food and nutrition (in-)security and social protection}

Rachel Slater, Rebecca Holmes and Nicholas Mathers

Overseas Development Institute, United Kingdom 


\section{Food and nutrition (in-)security and social protection}

Rachel Slater, Rebecca Holmes and Nicholas Mathers, Overseas Development Institute, United Kingdom

\section{Abstract}

Social protection measures are policy instruments that are widely used across a broad range of developing countries in pursuit of many different development objectives. In many cases social protection measures such as food or cash transfers were first introduced to ensure minimum levels of food security for vulnerable households. However, as the policy objectives became more numerous and varied, the relationship between food security and social protection have become less prominent. This paper refocuses attention on the linkages between social protection and food and nutrition security and aims to contribute to better integrated policies on food and nutrition (in-)security and social protection, particularly among Development Assistance Committee (DAC) members and their partners. The paper explores the conceptual linkages between social protection measures and food and nutrition security, examines the evidence of practical benefits that different social protection instruments can deliver and assesses the linkages between the two subjects in the international development policy agenda and concludes by proposing ways to better integrate the two issues within development policies and by identifying the main challenges and trade-offs that DAC members and their partners are likely to face.

OECD Working Papers should not be reported as representing the official views of the OECD or of its member countries. The opinions expressed and arguments employed are those of the authors.

OECD Working Papers describe preliminary results or research in progress by the author(s) and are published to stimulate discussion on a broad range of issues on which the OECD works. Comments on the present Working Paper are welcomed and may be sent to dac.contact@oecd.org - the Development Co-operation Directorate, OECD, 2 rue André-Pascal, 75775 Paris Cedex 16, France.

This document and any map included herein are without prejudice to the status of or sovereignty over any territory, to the delimitation of international frontiers and boundaries and to the name of any territory, city or area. 


\section{List of Acronyms}

\begin{tabular}{|c|c|}
\hline $\begin{array}{l}\text { APRLP } \\
\text { BMI }\end{array}$ & $\begin{array}{l}\text { Andhra Pradesh Rural Livelihoods Project } \\
\text { Bodv Mass Index }\end{array}$ \\
\hline CCT & Conditional Cash Transfer \\
\hline CFPR & Challenging the Frontiers of P overty R eduction \\
\hline CLP & Chars Livelihoods P roject \\
\hline DAC & Development Assistance Committee \\
\hline DFID & UK Department for International Development \\
\hline EPRI & Economic Polich Research Institute \\
\hline EU & European Union \\
\hline FAO & Food and Agrculture Organization \\
\hline FFA & Food for Assets \\
\hline GIZ & Deutsche Gesellschaft für Internationale Zusammenarbeit \\
\hline HGSF & Home-grown school feeding \\
\hline HIV/AIDS & Human Immunodeficiency Virus / Acquired Immunodeficiency Syndrome \\
\hline HLPE & $\begin{array}{l}\text { High Level Panel of Experts on Food Security and Nutrition of the Committee on World } \\
\text { Food Security }\end{array}$ \\
\hline IFAD & International Fund for Agricultural Development \\
\hline ILO & International Labour O rganization \\
\hline LIC & Low-income country \\
\hline MCDSS & Zambian Ministry of Community Development and Social Services \\
\hline MEGS & Maharashtra Employment Guarantee Scheme \\
\hline MIC & Middle-income country \\
\hline MPRLP & Madhya Pradesh Rural Livelihood Project \\
\hline OECD & Organisation for Economic Co-operation and Development \\
\hline P 4P & Purchase for Progress \\
\hline PROCAMPO & Programa de Apoyos Directos al Campo \\
\hline PROGRESA & Programa Nacional de Educación, Salud y Alimentación \\
\hline PSNP & Productive Safety Nets Programme \\
\hline PW P & P ublic Works Programme \\
\hline UCT & Unconditional Cash Transfer \\
\hline UNICEF & United Nations Children's Fund \\
\hline WFP & World Food P \\
\hline
\end{tabular}




\section{Table of Contents}

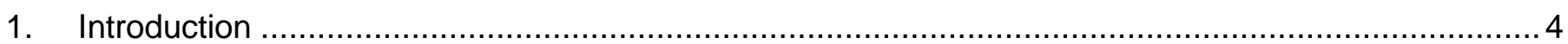

2. Interlinkages between food and nutrition (in-)security and social protection, in theory and in practice 5

2.1. What are the conceptual linkages between social protection and food and nutrition security? 5

2.2. Is there evidence to support that the conceptual linkages between social protection and food and nutrition security occur in practice?

2.3. Evidence on social protection instruments' contribution to food and nutrition security ........................ 7

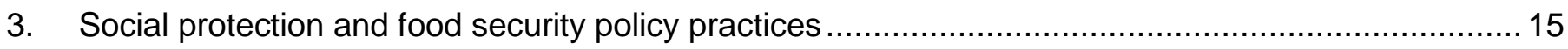

3.1. Policies and programming of international donor agencies and IFIs ..................................... 15

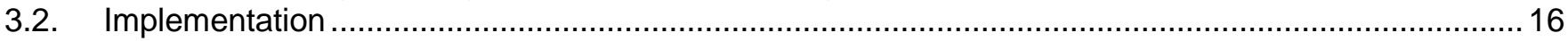

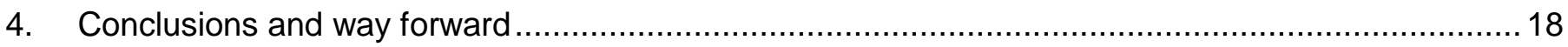

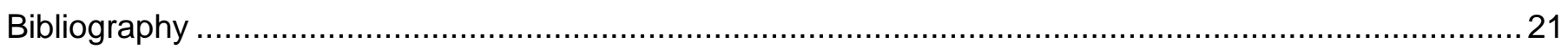

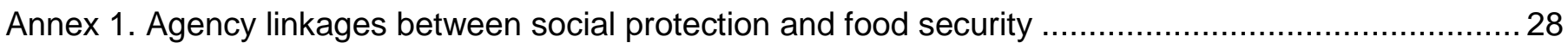

\section{Boxes}

Box 1. Key Issues: How can cash transfer programmes contribute to improved food and nutrition

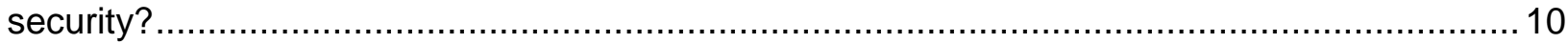

Box 2. Key Issues: How can public works programmes contribute to improved food and nutrition



Box 3. Key Issues: How can inputs transfer programmes contribute to food and nutrition security? .... 12

Box 4. Key Issues: How can food transfer programmes contribute to food and nutrition security? ....... 13

Box 5. Key Issues: How can integrated programmes contribute to improved food and nutrition security?

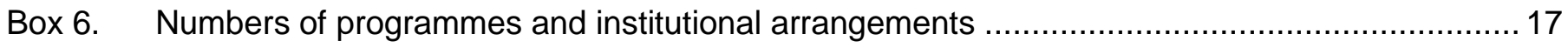

\section{Tables}

Table 1. Bilateral and multilateral agency and IFI linkages between social protection and food security .. 28 


\section{Introduction}

Across a range of developing countries, social protection is inspired by many different development objectives. In some places, the focus is overwhelmingly on tackling inequality and improving human development outcomes, as for example, in Latin America. Elsewhere, as in Eastern Europe and the Commonwealth of Independent States, the focus is chiefly on formal social security systems. In Africa and South Asia, social protection has emerged largely as a mechanism for tackling food insecurity, but in recent years, the social protection agenda has come to embrace a range of diverse and sometimes competing objectives: tackling life cycle vulnerability; addressing geographic and social exclusion; ameliorating the worst impacts of HIV/AIDS; and buffering households against food and fuel price volatility and the effects of global recession. Amidst these varied objectives, the linkages between food security and social protection have often been lost or become obscured. This paper refocuses attention on the linkages between social protection and food and nutrition security and aims to contribute to integrated development policies on food and nutrition (in-)security and social protection, particularly among Development Assistance Committee (DAC) partner agencies.

In this paper, we use a broad definition of social protection that includes "all public and private initiatives that provide income or consumption transfers to the poor, protect the vulnerable against livelihood risks and enhance the social status and rights of the marginalised; with the overall objective of reducing the economic and social vulnerability of poor, vulnerable and marginalised groups" (Devereux \& Sabates-Wheeler, 2004: 9). Using the framework of Devereux and Sabates-Wheeler (2004), the objectives of social protection policies and programmes can be categorised as protective, preventive, promotive and transformative; or a combination of these factors, with the intent of helping households manage and cope with vulnerability and risk and of bridging the gap between short-term needs and strategic investments (IFAD et al., 2012).

Protective social protection most often involves cash or in-kind transfers or fee-waivers, with the aim of providing for basic consumption needs such as food and health care, and alleviating chronic or transitory poverty. Preventive social protection involves insurance schemes such as pensions, or risk-pooling mechanisms such as health and unemployment insurance, in order to prevent a drop in living standards during crises or at less productive times in an individual's life. Both protective and preventive measures can help households avoid ill-advised coping strategies in times of crisis, such as selling productive assets or withdrawing children from school. Promotive social protection may include productive transfers, insurance and credit schemes, labour market interventions, investment in public assets and access to education or skills training. This provides the basis for economically vulnerable households and for those who are experiencing transitory poverty to more securely invest in human capital and livelihoods, leading to higher productivity and income. Transformative social protection aims to change discriminatory laws and practices that result in unequal access to social and economic resources and opportunities. This may include, for example, rights-based approaches to social protection, such as employment guarantees, redistribution of land to poor or marginalised groups, price controls and the protection of women's inheritance and employment rights.

By contrast with social protection, there is greater consensus around definitions of food and nutrition security. The focus of concern has long moved beyond issues of availability to a recognition of the importance of physical and economic access, stability, utilisation and appropriateness (FAO, 1996), with a focus on the welfare of the individual rather than on aggregate supply. Food insecurity, therefore, means that one or more of these conditions (availability, access and utilisation) has not been met for a household or individual, leading to acute, chronic or transitory hunger, depending on the severity and persistence of the failure. In line with this definition, recent communications by the Council of the European Union (2010) and the World Food Summit (2012) identify four focus areas for improving food security: i) increasing 
availability, ii) improving access, iii) improving the nutritional adequacy of food intake and iv) enhancing crisis prevention and management. The EU declaration further suggests that the priority should be to focus on i) poor and smallholder producers to meet future food demand, contribute to the United Nations Millennium Development Goal (MDG) 1, and reduce rural poverty and hunger and ii) improve access for people who suffer hunger and malnutrition due to poverty or other vulnerability, and who lack the resources for farming. The Food and Agricultural Organization (FAO) definition of food security (1996) captures many elements of nutrition security (nutritional content appropriate to specific needs and preferences), so we use that single definition in this paper. We do, however, attempt to stress the broader nutrition outcomes of social protection programmes (e.g. where school feeding programmes include educational information on food hygiene).

The following section of this paper further describes the different pathways by which social protection and food security are linked, both in theory and in practice. Section 3 highlights the linkages between the two subjects in the international development policy agenda; and Section 4 concludes by proposing ways to better integrate the two issues in terms of development policies and identifying the main challenges and trade-offs that DAC partners are likely to face.

\section{Interlinkages between food and nutrition (in-)security and social protection, in theory and in practice}

\subsection{What are the conceptual linkages between social protection and food and nutrition security?}

A framework for understanding the different dimensions and sources of food and nutrition (in-)security relate to the four pillars of availability, access, nutrition, and crisis prevention and management (EU, 2010; W orld Food Summit, 2012).

Food availability refers to the supply of food, i.e. a country's ability to provide enough (nutritious) food to meet the needs or demands of the population, either through domestic production or food imports, and to provide sufficient nutrition-related services (Ecker \& Breisinger, 2012; Pinstrup-Andersen, 2009). Social protection instruments can directly support food availability through two main mechanisms: i) increasing agricultural production or productivity, for example, by transferring free inputs or assets (e.g. fertilisers, seeds, livestock, machinery); and/or ii) supporting market supply (controlling prices and reducing volatility) for example, building roads that improve access to markets or distributing vouchers and organising seed and livestock fairs, where competition between participating traders is expected to lower prices for beneficiaries as well as non-beneficiaries (Freeland \& Cherrier, 2012). Other types of social protection instruments can also have a positive effect on the availability of food. Cash transfers can reduce credit constraints, enhancing access to inputs and thereby raising agricultural productivity (Barrientos $\&$ Scott, 2008) and programmes that raise household income (directly, through cash transfers, or indirectly, through subsidising goods and services) may also increase demand for food, stimulating local food market supply. Similarly, school feeding programmes, such as those that procure food locally or Purchase for Progress (P 4P) initiatives, may also promote the supply side of local food production (HLPE, 2012).

Food access centres on the ability to produce and/or purchase sufficient nutritious food. This is the area where the conceptual linkages between social protection and food and nutrition security are the strongest. The main mechanisms by which social protection programmes improve household access to food are through instruments that focus on "protection" or "prevention" objectives through i) the direct transfer of food, ii) smoothing or raising household income and iii) improving subsistence farming production. Food (and voucher) transfers and school feeding programmes 
directly increase food consumption. Cash transfers (e.g. in Mexico and Malawi) or cash-for-work (e.g. Ethiopia) can directly and immediately increase household income to spend on food, especially in times where food or employment is scarce; agricultural insurance mechanisms can smooth income and reduce the risk associated with farming (e.g. harvest failure or livestock losses) (HLPE, 2012); asset-transfer programmes (e.g. in Bangladesh and Zimbabwe) are expected to increase household income, although in the medium term; and in-kind transfers, subsidies or service fee waivers can have an indirect effect on household income by releasing income that would have been spent on other goods or services and can be redirected to expenditure on food. Across the range of programmes that increase household income or transfer food, such as cash transfers in Latin America, public works programmes (PWPs) such as the Productive Safety Nets Programme (PSNP) in Ethiopia, supplementary feeding, fortified school meals and take-home rations (Freeland $\&$ Cherrier, 2012), improvements in diet in terms of quality, quantity and diversity, including greater access to micronutrients, can often be seen. Improvements in subsistence farming can also be achieved through social protection programmes, either directly (such as input transfers or subsidy programmes) or through cash transfer and PWPs in which household income is spent on agricultural inputs to enhance own-farm productivity.

Food utilisation is concerned with improving the nutritional adequacy of food. Positive nutritional outcomes can be encouraged by the better utilisation of food and improvements in ancillary areas, such as drinking water, hygiene, sanitation, child care practices and health care (Freeland \& Cherrier, 2012). Illness and disease, for instance, can reduce the absorption of nutrients. Access to clean drinking water; adequate sanitation; advice on child care (such as sound feeding practices); basic health care, and illness treatment and prevention, including immunization and related information and education campaigns, all determine nutritional status indirectly through the link with health (Fay et al., 2005; F rongillo et al., 1997; Smith et al., 2005 cited in Ecker \& Breisinger, 2012). Intra-household dynamics and household preferences are also important to consider, because decision-makers in a household may not prioritise food acquisition or nutritious food over other goods and services. Robust evidence demonstrates that mothers' education, knowledge and decision-making are closely correlated with improved nutrition outcomes, especially for children.

Health fee waivers, health care subsidies, social health insurance or social protection programmes that integrate free or subsidised health care, including immunisations, may facilitate improvements in basic health status for both adults and children.

Integrated social protection programmes that include training and awareness-raising may improve nutritional knowledge and promote good sanitation practices. Educational efforts on nutrition and social development issues are most often directed at women, on the grounds that women are the household and food managers. In theory, programmes that specifically target resources towards women, such as cash transfers, contribute to increased food and nutrition security on the assumption that this empowers women and consequently increases their decision-making and control over the resources spent on food.

Finally, the fourth pillar of food security is concerned with enhanced crisis prevention and management. In theory, social protection instruments can be scaled up or refined in the short term, as a response to sudden shocks or recurrent cyclical stresses, such as cash transfers that are combined with food transfers or emergency PWPs. Social protection instruments may also act as a longer-term response to predictable shocks through building individuals' livelihoods and their ability to cope with future crisis, such as the integrated programme in Zimbabwe or Ethiopia's PSNP.

\subsection{Is there evidence to support that the conceptual linkages between social protection and food and nutrition security occur in practice?}

While the discussion above focused on the conceptual and theoretical linkages between social protection and food and nutrition security, this section looks at the evidence that can demonstrate that these linkages occur in practice. We do this by i) examining the available evidence (from 
methodologically robust sources wherever possible) across a range of social protection instruments referring to the four pillars of food security, and recognising that there are strong linkages and overlaps between the four pillars, and ii) briefly discussing the main ways in which practical programming experience shows how positive contributions can be made (e.g. through particular design or implementation features).

\subsection{Evidence on social protection instruments' contribution to food and nutrition security}

The evidence on social protection programmes contributing to household access to food is relatively robust, showing that across a range of social protection programmes, both productivity-focused and protection-focused increased household income is spent on increasing the quantity and also the quality of food consumed. A number of social protection interventions also have an important role to play in mitigating the effects of shocks or seasonal stresses on household food insecurity, through smoothing consumption and/or income.

Only a few social protection instruments have as a direct objective increasing agricultural productivity, and thus contribute to supporting food availability. At the household level, integrated programmes, input transfers and subsidies and PWPs have the most direct link. However, other programmes more focused on protecting household income and consumption can also have indirect impact on increasing productivity and stimulating markets.

Most of the evidence showing that social protection contributes to improved utilisation of food comes from Latin American experiences of Conditional Cash Transfers (CCTs). In addition, there is some evidence from PWPs, school feeding and supplementary feeding. We look at the evidence on specific social protection instruments in detail below.

Cash transfers and food access: A review of the evidence on cash transfers by the United Kingdom's Department for International Development (DFID) (2011) found that "one of the strongest and most consistent findings regarding the impact of cash transfer programmes is their contribution to reducing hunger and food insecurity. Regardless of the form of transfer, households receiving transfers average significantly higher spending on and consumption of food. The impact of cash transfers on hunger has been most pronounced in lower-income countries (LICS) where poverty is generally more severe. In these settings, households receiving additional income are particularly likely to prioritise spending on improving the quantity and or/quality of food consumed" (DFID, 2011: 20). Evidence from countries in sub-Saharan Africa and Latin America confirm this (Adato \& Bassett, 2008; Fiszbein \& Schady, 2009; Vincent \& Cull, 2009): in Malawi, 75\% of a cash transfer was spent on groceries (Vincent \& Cull, 2009); for CCTs in Colombia, Mexico, Honduras and Brazil significant impacts on per capita consumption were found, ranging from $7 \%$ to $10 \%$ (Fiszbein \& Schady, 2009).

Increased income is also invested to improve household agricultural production for own consumption. Households receiving South Africa's Child Support Grant showed greater resilience in terms of maintaining agricultural production (EPRI, 2011, cited in DFID, 2011). In Bolivia, households receiving a social pension in poor rural areas experienced an average increase in food consumption of almost $165 \%$ of the value of the transfer. This was achieved through the investment of part of the transfers in agricultural inputs. ${ }^{1}$

The positive effects of cash transfers depend on the existence of well-functioning local food markets. W ithout access to markets, or if prices are raised, the purchasing power of cash transfers is significantly lower. Cash transfers are rarely index linked, and are thus reduced in value in situations of inflation or supply failure (HLPE, 2012), but they can still help to mitigate the negative

\footnotetext{
${ }^{1}$ The social pension, BONOSOL, is paid once a year to persons aged 65 and over. At USD 246, it is a significant injection of liquidity for rural farmers who have land but no cash or credit to purchase seeds and other agricultural inputs (Martinez, 2007, cited in Barrientos and Scott, 2008).
} 
effects of crises and emergencies by smoothing income and consumption. The challenge is to maintain their real value when markets are volatile. There is very little evidence on the effect of long-term cash transfers in economic downturns or crises, but in emergencies, short-term transfers can help to increase access (and utilisation) of food (Bailey \& Hedlund, 2012).

Cash transfers and food availability: Whilst in theory cash transfers can promote agricultural production through investment of the cash in productive activities as well as by stimulating markets, there is no evidence of increases in aggregate growth in agricultural production at the national level (Barrientos \& Scott, 2008) (although there is some evidence at local level, discussed in more detail below). At household level, the Malawi social cash transfer programme was found to lead to increased investment in agricultural assets, including crop implements and livestock. Brazil's social pension is also partly invested in seeds and tools for farming (HLPE, 2012). Studies have also observed a rise in investment by beneficiary households under Mexico's conditional cash transfer, the Programa Nacional de Educación, Salud y Alimentación (PROGRESA, now Oportunidades) compared to non-beneficiaries. Gertler et al. (2006) estimate that on average, around $12 \%$ of transfers to beneficiaries were invested in productive assets. Sadoulet et al. (2001), who compared transfers under PROGRESA and Programa de Apoyos Directos al Campo (PROCAMPO), a human development conditional transfer programme and a productive transfer to owners of small farms respectively, find that the latter had income multipliers of around 1.5 to 2.6 (Barrientos \& Scott, 2008). ${ }^{2}$

The impacts of cash transfers on markets are mixed. In remote areas of South Africa, cash transfers have stabilised the demand for food, reduced market risk for producers and traders, and supported local agricultural production (Samson et al., 2007, cited in DFID, 2011). The social pension in Namibia also improved market access to food by attracting traders to remote communities and enabling pensioners to buy food on credit (Devereux, 2002, cited in HLPE, 2012). However, where markets are not able to respond to increased demand by increasing supply, cash transfers can have a negative impact, by pushing up local prices. In Ethiopia, the Meket Livelihoods Programme shifted from food- to cash-based transfers, with negative impacts on the availability and price of food in local markets for beneficiaries, especially in remote, areas with food deficits (Kebede, 2006; DFID, 2011). This is particularly important in the context of crisis.

Unconditional cash transfers and nutrition: The Kalomo District Pilot Social Cash Transfer Scheme in Zambia significantly improved the diets and nutritional status of beneficiaries - consumption of fats, proteins and vitamins increased, and the percentage of households living on one meal a day fell from $19 \%$ to $13 \%$ (MCDSS \& GTZ, 2006). A number of studies show positive impacts on height-for-age, weight-for-height and nutrition from unconditional cash transfers (UCTs), as well as CCTs (see below). Children in South Africa whose mothers receive the Child Support Grant are predicted to increase their height-for-age, so they will be 3.5 centimetres taller as adults (Aguero et al., 2007 cited in HLPE, 2012). In Malawi, the Mchinji Social Cash Transfer Scheme found that the proportion of children in beneficiary households whose growth was stunted fell from $55 \%$ to $46 \%$ in one year, but remained at $55 \%$ in "control group" households that did not receive transfers. The proportion of children who were wasted more than halved over the year, from $16.2 \%$ to $7.2 \%$ in beneficiary households, but also fell significantly

\footnotetext{
${ }^{2}$ Gertler et al. (2006) provide extensive evidence on this Mexican experience. They find that the programme had a substantial positive impact on investment in productive activities such as microenterprises and agriculture (animals and land). On average, $12 \%$ of transfers were invested, and households that received more transfers from Oportunidades also invested more. It seems that the CCT helped alleviate two market failures. First, the increased income allowed households to overcome credit constraints. Second, the stable stream of income may have made households willing to undertake more risky (and profitable) investments. Another study (Maluccio, 2008) assesses the impact of the Red de Protección Social (RPS) program in Nicaragua on various types of investments. The author finds only limited evidence that the programme led to an increase in investment for agricultural equipment. In contrast to Mexico, however, there was only weak (albeit positive) evidence that RPS improved investment activities, possibly because of an economic downturn during the period, the strong programme orientation toward increased food expenditures, and the limited opportunities in the impoverished rural areas where the programme operated (Fiszbein \& Schady, 2009).
} 
in non-beneficiary households, leaving an attributable "difference in differences" of 2.2 percentage points (Miller et al., 2011: Fig. 3, cited in HLPE, 2012).

Conditional cash transfers and nutrition: The Committee on World Food Security's High Level Panel of Experts on Food Security and Nutrition (HLPE) (2012) note that there is a need to focus on the actual forms of feeding programmes, which can vary greatly. They argue that it is desirable to link transfers to interventions that can facilitate behavioural changes that will empower mothers and families to ensure adequate nutrition of children, prepared at home from local resources where appropriate. This "integrated" approach, which often includes cash payments along with training or awareness sessions on, for example, nutrition, health, care practices, sanitation and hygiene, and access to free health care, is being implemented through a number of conditional cash transfers (CCTs) (for example, in Mexico and Peru, cash is accompanied by nutrition education for caregivers) and integrated social protection programmes such as the Chars Livelihoods Programme (CLP) and Challenging the Frontiers of Poverty Reduction (CFPR) in Bangladesh, which integrate both economic and social development training (discussed below). While it is difficult to distinguish which components contribute to improved food security, the evidence on diversity of diet is very positive (from CCTs, UCTs and integrated programmes), whereas anthropometric impacts from CCTs in particular are mixed, indicating that other factors influencing nutrition are at play.

Households that benefited from Familias en Acción in Colombia significantly increased items rich in protein, such as milk, meat and eggs (Attanasio \& Mesnard, 2006); and the increases in food expenditures in Mexico and Nicaragua were driven largely by increased consumption of meat, fruits and vegetables (Hoddinott et al., 2000; Maluccio \& Flores, 2005). Mexico's Oportunidades also increased caloric diversity, as measured by the number of different foodstuffs consumed (Fiszbein \& Schady, 2009).

While some positive impacts using anthropometric indicators are found in a few CCT programmes, there is no general positive trend. Indeed, programme outcomes are mixed. For instance, CCTs have demonstrated a reduction in malnutrition in Mexico and Nicaragua (Maluccio \& Flores, 2005) and increases child height of approximately one centimetre in Mexico, (Fiszbein \& Schady, 2009). However, there is no evidence that positive initial impacts observed in Oportunidades were sustained over time (Neufeld et al., 2005, cited in Fiszbein and Schady, 2009). Nicaragua's Atención a Crisis programme has had no impact on child height among children of any age group (Macours et al., 2008). And in Honduras, the Programa de Asignación Familiar (PRAF) had no effect on child height (Hoddinott, 2008). These effects have been argued to be attributable in part to the small size of transfers and lack of complementary services (Yablonski \& O 'Donnell, 2009). 


\section{Box 1. Key Issues: How can cash transfer programmes contribute to improved food and nutrition security?}

- Food access and nutrition: In order for cash transfers to deliver food security and nutrition outcomes, the level of cash transfer must be adequate (e.g. in relation to food basket costs or contribution to household monthly consumption expenditure), and transfers must be predictable, regular and delivered over time: the higher the transfer level and the longer households receive it, the more positive the effects on access to food and nutrition. Also, nutritional needs of household members vary according to life-cycle needs (for instance nutritional needs of pregnant and nursing mothers and the "thousand-day window" for tackling child malnutrition). Finally, the availability and use of complementary services also demonstrate important potential impacts, such as increasing knowledge on nutrition, health and sanitation and access to health care services. More rigorous evidence is needed on the impact of these combined approaches.

- Crisis prevention: There is little evidence of the impact of long-term cash transfers significantly reducing vulnerability to short-term shocks; however, long-term and short-term emergency cash transfers need to consider index-linking the price of transfers and the functionality of markets (and therefore whether combinations of cash, vouchers and food would be more appropriate).

- Productivity: Tensions between the objectives of cash transfers (for consumption or investment) need to be explicitly considered. The expectations of cash transfer programmes promoting investment in productive activities (in terms of transfer levels and time available, especially for women with additional care work responsibilities) need to be realistic, and the timing of the transfer (e.g. one-off "lumpy" payments or regular transfers, as well as seasonal considerations) appropriate. Expectations concerning the impact on productivity should be adapted to the target group of the cash transfer. Credibility (ie that people believe that payments will come and be on time) is essential and programmes of longer duration are necessary for systemic impacts on productivity.

Public works programmes and food access: The strongest contribution of public works to food security is to food access through direct payments of wages in food, or by increasing income through wages that are subsequently spent on food. A recent evaluation of the PSNP in Ethiopia found that for households that had participated for only one year and received much lower levels of transfers, the PSNP improved food security by 1.05 months. When the programme began, participating households reported, on average, 3.6 months of food insecurity each year, so this represents an attributable reduction in food insecurity of 30\% (Berhane et al., 2012). Other PWPs also show improvements in food consumption. Households participating in Food for Assets (FFA) and the Rural Maintenance Programme (RMP) in Bangladesh increased their per capita food consumption by 23 and 35 kilocalories per day respectively, for every taka ${ }^{3}$ (BDT 1) of income transferred (Ahmed et al., 2010b cited in HLPE, 2012). The level of the transfer is a critical factor. In PWPs, wages are often kept low because of perceived concerns about "handouts" and disruptions to local agricultural casual labour markets and rates (McCord, 2013). Jalan and Ravallion (2003, cited in McCord, 2013) find that in the Maharashtra Employment Guarantee Scheme (MEGS), taking the forgone wage labour opportunities into account, the net value of the wage decreases to half of the gross wage.

In the context of crises, the impacts of PWPs are also mixed. McCord (2013) states that the length and scale of programmes are critical for access to food security, noting that only in programmes that are long-term and operating at scale (such as the PSNP in Ethiopia and the Mahatma Gandhi Rural Employment Guarantee Scheme in India) can impacts be seen on positive labour market effects, and as a consequence, better access to food and nutritious diets. Evidence from the PSNP demonstrates that it can protect food security and asset levels in the presence of repeated shocks. In Ethiopia, households living in areas that experienced a minimum of two droughts but that also received PSNP payments for two or more years were able to maintain their existing levels of food consumption (HLPE, 2012).

${ }^{3} 1$ taka = approximately USD 0.01 
Public works programmes and food availability: There is relatively little evidence to confirm that the rural infrastructure created in PWPs leads to improved productivity, both in response to mitigating negative effects of shocks (e.g. through construction of flood defences) as well as longer-term benefits, such as improving soil and water conservation or improving market integration. A key challenge here is that when PWPs are one-off emergency interventions, the creation of assets are rarely well planned, and as such have only short-term or limited value (McCord, 2013). Evidence from PWPs in Bangladesh and Ethiopia are exceptions, demonstrating positive effects on supporting market access and increased productivity. In Bangladesh, the FFA and PWPs contributed rural feeder roads that connect remote villages to major highways. This infrastructure has also been used to move food to needy communities during emergencies (HLPE, 2012). In Ethiopia, households with access to both the PSNP as well as complementary packages of agricultural support were found more likely to be food-secure, to borrow for productive purposes, to use improved agricultural technologies, to operate their own non-farm business activities, to achieve higher grain production and to make greater use of fertiliser (IFAD et al., 2012).

Public works programmes and nutrition: Maharashtra's MEGS, a PWP, improved the health and nutritional status of participating women and their children (Dandekar, 1983, cited in HLPE, 2012). However, one evaluation in Niger recorded lower body mass index (BMI) scores for public works participants than for non-participating adults in the same household (Webb, 1995, cited in HLPE, 2012). The wage levels set are vitally important for public works, as the energy expended performing manual labour reduces the net nutritional impact of the food or cash wages.

\section{Box 2. Key Issues: How can public works programmes contribute to improved food and nutrition security?}

- Food access and nutrition: Similar to the key issues in cash transfers discussed above, if PWPs are to deliver food security and nutrition outcomes, they must be long-term, be able to deliver at scale adequate wage levels, frequent and reliable payments. Considerations of the wage level in relation to energy expended on the manual public works components are particularly important. It is also important to consider gender issues, such as who in the household works and receives payments (e.g. women with access to and control over income are likely to provide better nutritional outcomes for their families).

- Crisis prevention: It is not only wage levels that are important in the role of public works in reducing household vulnerability to food insecurity in times of shocks and stresses. Also significant are the timeliness of employment in relation to seasonal income and food fluctuations, the scale of interventions, as well as the appropriateness of assets created. There will be limited impact on incomes and food security unless the programmes are implemented at scale and are operating long-term.

- Food availability: The creation of assets under PWPs has the potential to contribute to agricultural productivity, but such programmes are often not well planned or maintained. Opportunities to improve the contribution of community assets to increasing productivity include ensuring that assets are built based on need and that they are of quality, accessible to the poor and sustainable. The availability of complementary interventions can also help recipient households and communities benefit from the wages and assets (such as agricultural extension, microfinance and skills training), but they need to be well implemented for these linkages to occur.

Evidence on inputs transfers and subsidies and food availability: Inputs subsidies have been found to have positive impacts on agricultural production and farmers' incomes. For instance, evidence from Malawi's Farm Input Subsidy Programme shows increases in maize production attributable to the fertiliser subsidy (although some of the increase is undoubtedly due to favourable rains since 2005) (Minot \& Benson, 2009, cited in HLPE, 2012; Dorward et al., 2008 cited in HLPE, 2012). Similar positive impacts are found in India at the national level, where the input subsidies contributed significantly to accomplishing national-level food security and national self-sufficiency in staple cereals, rice and wheat (HLPE, 2012); as well as at the state level, where farm productivity in West Bengal increased $17 \%$ in $1982-85,16 \%$ in $1986-90$ and $8 \%$ in $1991-95$ (Bardhan \& Mookherjee, 2011 cited in HLPE, 2012). In the case of input transfers, the evidence is mixed, with many direct transfer programmes plagued with implementation problems. However, in 
the case of Malawi, Harrigan (2005) finds impacts on availability, access and utilisation of food, and notes that only in years where the government intervened with universal free input delivery (1998-99, 1999-2000 and 2002-03) was the country able to produce a surplus or near-surplus in maize production.

\section{Box 3. Key Issues: How can inputs transfer programmes contribute to food and nutrition security?}

- There are a number of challenges associated with inputs programmes, including that national-scale input subsidy programmes are expensive and inefficient if generalised, and can result in negative secondary impacts on trade, markets and the environment. To overcome these challenges, the general donor approach is to target poor smallholders and avoid large leakages to richer farmers, and include complementary interventions. For example, in the case of West Bengal, institutional reforms including land redistribution and tenancy registration protected sharecroppers against eviction and regulated the crop share they could retain.

- Other alternatives should be considered, such as a targeted cash transfer equivalent to the subsidy, delivered immediately prior to the planting season (e.g. Mexico's PROCAMPO) (HLPE, 2012).

Evidence on food transfer programmes and food access: School feeding programmes can improve consumption, although drawing generalised conclusions on the food security impacts of school feeding is complicated, because of significant variations across the quantity and quality of food provided, and whether the food is fortified with micronutrients. A school snack programme in the Philippines increased calorie consumption of primary school-age children by about $300 \mathrm{kcal}$ per child per day (J acoby, 2002 cited in HLPE, 2012). Importantly, parents did not reduce the amount of food served to children at home, a finding replicated in other countries such as Bangladesh (Ahmed, 2004, cited in HLPE, 2012). Importantly, existing school feeding programmes may also serve as good platforms for scaling up social protection in response to shocks such as drought, because the necessary infrastructure for delivery is already in place. The assurance of free meals during a food crisis can also contribute to keeping in school children who might otherwise be withdrawn to save costs or to look for work (HLPE, 2012).

Food transfer programmes and food availability: Certain types of food transfer programmes can promote agricultural production. "Home-grown school feeding" (HGSF) is an approach that sources food for school feeding locally (preferably, but not always, poor smallholders), rather than using imported food or food aid (HLPE, 2012; Sumberg \& Sabates-Wheeler, 2011). Otsuki and Arce (2007) use Brazil's experience as an example, stating that "reforms in the mid-1990s led to the decentralisation of procurement, both improving delivery and stimulating local production" (cited in HLPE, 2012: 43). WFP's Purchase for Progress (P4P) is another example where local procurement is a key feature. $\mathrm{P} 4 \mathrm{P}$ works on the premise that food transfers positively impact the food security of recipient communities (demand side) as well as improving the livelihoods (and thereby, food security) of small-scale, poor producers (supply side). Evidence from P 4P suggests additional demand has been created, leading to higher prices, which in turn have provided a production stimulus, leading to an increase in food supply and availability (USDA, 2009; Ferguson $\&$ Kepe, 2011, cited in Coles, forthcoming).

Evidence on an extended link between supplementary feeding and productivity is also given by Hoddinott (2008) and Maluccio et al. (2009) from a randomised intervention in Guatemala that showed that supplementary feeding improved cognitive skills, schooling and adult economic productivity, showing how social transfers (as an in-kind transfer provided to young children) can also act as long-term economic investments. However, this is the only evidence available for this type of pathway.

Food transfer programmes and nutrition: A number of studies found positive impacts on micronutrient status from school feeding programmes. In Uganda, a decline in the prevalence of 
mild anaemia was found among adolescent girls aged 10-13 years (Adelman et al., 2012 ${ }^{4}$ ) and the take-home ration component showed a decline in mild anaemia prevalence of adult women aged 18 and older living in households that received these rations. Ahmed (2004) and Kazianga et al. (2009) also report positive spill-over effects to other household members, most notably younger siblings (HLPE, 2012). In the cases of HGSF and P4P, locally procured food, as long as it is viewed as of high quality and safe, is heavily preferred over internationally sourced rations, contributing to enhanced utilisation by households (Coles, forthcoming). Positive impacts are also found from supplementary programmes. Studies undertaken in G hana (Adu-Afarwuah et al., 2007), Guatemala (Schroeder et al., 1995), Haiti (Ruel et al., 2008) and J amaica (Sguassero et al., 2005) show positive impacts on height gain, while others in Ecuador (Lutter et al., 2008) and Malawi (Lin et al., 2008) find evidence of gains in weight but not height (HLPE, 2012).

\section{Box 4. Key Issues: How can food transfer programmes contribute to food and nutrition security?}

- Food access and nutrition: Evidence suggests that food transfers can have important impacts on nutritional status, but also that the quality of food and the options for fortified food are critical issues.

- Crisis prevention and management: Food transfers such as food aid and school feeding programmes have the potential to scale up in the context of emergencies, because existing infrastructure and delivery mechanisms are in place.

- Food availability: Recent focus on the supply side of food transfer programmes has enabled programmes to enhance smallholder productivity, but more information is needed about how these programmes work in practice.

Integrated programmes and food availability: Integrated programmes from Bangladesh and India provide some useful insights into how combinations of programme components can contribute to the pillars of food security in practice. In Bangladesh, the Chars Livelihoods Programme (CLP) and Challenging the Frontiers of Poverty Reduction (CFPR) are both asset transfer programmes that are built on a model of "graduation", providing an asset transfer (usually of livestock) to women, coupled with a regular stipend for 18 months, skills training, a savings scheme and social development awareness-raising sessions on issues such as health and sanitation and nutrition. In India, a number of rural livelihoods projects in states such as Madhya Pradesh (MPRLP) and Andhra Pradesh (APRLP) focused primarily on promoting rural agricultural production and enhancing skills for female farmers working in the agricultural sector.

Evidence from the rural livelihoods projects in India demonstrates significantly increased agricultural production and productivity, although we do not know the extent to which increased agricultural outputs are consumed or are sold, thereby contributing to improved food availability or access (Reid, 2010). In such programmes, where agricultural productivity is a main programme objective, interventions have resulted in increases in the production of additional crops (in the rabi season in India), improvements in land-based productivity resulting in increased yields, and a greater diversification in agriculture (ibid.). These results have been achieved through the combined and integrated approach to rural livelihoods, including improved animal husbandry, forestry, aquaculture and horticulture, small-scale, participatory soil and water conservation techniques, improved soil fertility and improved water-holding status and improved use of technology in the India programmes (ibid). In Bangladesh, where the primary focus of the "graduation" model programmes is to generate income through assets such as livestock, programme evaluations still report an increase in productivity due to complementary programme interventions in vegetable and homestead gardening. In the case of CLP, for instance, beneficiaries receive skills training in homestead gardening and the provision of quality seeds and fruit saplings, as well as assistance in developing compost pits and in marketing of surplus products (Marks \& Vignon, 2009).

\footnotetext{
${ }^{4}$ Data collected as part of a cluster randomised control trial.
} 
Integrated programmes and food access: Increased incomes, diversification of incomes and access to financial services (such as credit or savings) are important features identified as contributing to better access to food from the integrated programmes. This is particularly the case in the context of seasonal consumption and employment fluctuations and emergencies, where beneficiaries self-report an increase in the number of meals that they are able to eat (or a reduction in the number of meals that they miss). Qualitative evidence from the CFPR shows increased expenditure on food attributed to the availability of the regular cash stipend during the first 18 months of programme participation, and a stronger asset base generated by the programme's transfer (Hashemi \& Umaira, 2011; Rabbani et al., 2006). Similarly, evidence from livelihoods programmes in India suggests that combining consumption credit and activities to promote livelihoods diversification is a key contributing factor smoothing consumption over periods of food insecurity (Farrington, 2010). In CLP, Bangladesh, the availability of short-term public works (also found in India's APRLP) is seen as a critical factor, which ensures consumption smoothing in the monga season (Conroy, 2008).

Another key finding is the importance of increased access to food through community-run grain and seed banks in the India livelihoods projects MPRLP, APRLP and the Western Orissa RLP (WORLP), in order to respond to predictable seasonal and unpredictable shocks and stresses. An important function of the grain banks are that they are able to respond much more quickly to local food shortages than centralised food security programmes (Reid, 2010).

Integrated programmes and nutrition: Despite the evidence on improved food availability and access across the livelihoods programmes, there is limited evidence on this translating into better nutritional status. An exception is Bangladesh's CLP, where nutritional surveys in 2009 found that children of earlier recruits into the programme were, on average, less stunted and less underweight than later recruits (DFID, 2011). Another study from the CLP however, shows some improvements in women's BMI but no significant differences in under-5 wasting and stunting between beneficiary and treatment groups (Goto \& Mascie-Taylor, 2010; Mascie-Taylor, 2010).

While both the Bangladesh programmes also include "social" type trainings and awareness (such as nutrition education, hygiene awareness and water and sanitation interventions) it is difficult to assess the extent to which these components have contributed to improved nutrition. There are possible explanations for this. One is that although beneficiaries receive education and awareness training, they do not put it into practice. Another is that it is very difficult to separate out the impacts of different components in an integrated programme.

\section{Box 5. Key Issues: How can integrated programmes contribute to improved food and nutrition security?}

- Food access and nutrition: Evidence shows that integrated programmes can contribute to better access to food and nutrition outcomes; however, evidence on nutritional status is weak. There is potential for programmes that provide access to complementary services such as health services and awareness- raising and knowledge on nutrition, health and sanitation to contribute significantly to better nutritional status; however, there is weak evidence on the role that the different social programme components play.

- Crisis prevention: The role of integrated programmes in reducing vulnerability to seasonal shocks and stresses is strong, with beneficiaries reporting improved coping strategies. The range of interventions that beneficiaries receive is important in terms of providing short-term income and consumption smoothing, grain reserves and longer-term investments to diversify income sources.

- Food availability: One of the strongest impacts of integrated programmes is increased production as a result of a specific focus on agricultural productivity, which included integrated programme components to increase productivity, diversify crops and utilise new technologies. 


\section{Social protection and food security policy practices}

\subsection{Policies and programming of international donor agencies and IFIs}

Bilateral and multilateral agencies and the International Financial Institutions (IFIs) have diverging agendas on social protection. Some are very closely and directly tied to food security objectives, whilst others focus on other development objectives and make less direct and less tangible links to food security. Annex 1 provides examples of how a range of DAC partners and other international agencies delivering social protection have articulated linkages between social protection and food security and how these are reflected in their programming. What makes agencies link social protection and food security in their programming? A number of factors are important, including institutional mandates and functions, geographical experience and foci, and how and to whom different agencies are accountable.

First, institutional mandates have a strong influence on how agencies articulate the linkages between social protection and food security. Organisations mandated to work on food, like the FAO and World Food Program (WFP), incorporate access to and availability of food into their social protection activities explicitly and directly. Those responsible for specific social or demographic categories (e.g. UNICEF) start with supporting specific beneficiary groups as their primary aim, rather than food security as a leading objective. That is certainly not to say that food security is ignored by the United Nations Children's Fund (UNICEF), rather that food security is generally seen as a means to an end (improving the well-being of specific vulnerable groups), rather than as an end in itself. Similarly, the mandate of the International Labour Organization (ILO) on social protection is aligned with ILO's Social Security (Minimum Standards) Convention, 1952 (No. 102), which leaves limited scope for a very direct engagement on food security. Bilateral agencies simultaneously addressed a broader range of objectives, and often have a multiplicity of different approaches, programmes and policies.

Second, the different functions of agencies are also important. Lending organisations tend to focus social protection efforts on enhancing productivity, whilst grant-making organisations have more scope to deliver support to basic consumption. Existing experience, capacities and knowledge in donor agencies also have a strong influence on the extent to which programming focuses on food security or other objectives, in particular the choice of instrument. Third, the geographical foci of different agencies are important. Food security challenges in countries in Africa and South Asia are generally of a different order and scale from those in Southeast Asia and Latin America. Depending on their current and historic focus, agencies tend to articulate the linkages between social protection and food security differently. In Africa and many parts of South Asia, the preoccupation tends to be with using social protection to secure adequate (quantity of) calorific consumption, whilst in Latin America and among middle-income countries (MICs) in Southeast Asia the focus is much more on the quality and diversity of diet. Overall, agencies that focus more on low-income countries (LICS), particularly in South Asia and Africa, tend to focus their social protection programming more on food security objectives, whilst those that focus on MICs, especially in Latin America and parts of Southeast Asia, tend to focus more on building human capital.

Finally, DAC partner countries are also accountable to their domestic governments and citizens, and this influences the extent to which agencies focus on food security and/or social security objectives. For example, in Scandinavian countries, commitments to supporting long-term social security programming are more acceptable than among other partners. Elsewhere, there is less domestic support for social security programmes resulting in a focus on shorter-term investments in achieving food availability (through investments in agriculture), and food access (through food transfers) tends to dominate programming. 
The range of factors influencing whether and how social protection and food security are linked in programming are many, and so there are many potential outcomes. Overall, patterns of programming and approaches are difficult to find, and there are no typologies of agency responses. Monitoring social protection programme performance against specific food security indicators is not commonplace in most donor-supported social protection programmes, and where they take place, they tend to be based on self-reporting of nutritional status. Exceptions include the Ethiopia PSNP, a number of programmes in Bangladesh, and WFP or UNICEF programmes that work on stunting and wasting among children and on maternal health. Where agencies do use social protection to tackle food insecurity, they frequently incorporate both protective, preventative and productive elements in their programmes, resulting in high expectations of what social protection programmes can achieve. This is especially true in longer-term programmes, as many short-term humanitarian responses focus solely on supporting basic consumption.

\subsection{Implementation}

Incorporating food security objectives into social protection programming has implications for delivery in a number of ways.

There are many patterns of institutional arrangements for delivering social protection within government agencies, some of which are better suited when food security objectives are part of social protection programming. In general, where food security is a primary or major objective, or where particular types of programmes are used (such as public works or inputs vouchers) it is common for programmes to be located in Ministries of Agriculture, Food Security or Rural Development. This is most common in LICs. In countries where the focus is more on social security-type programmes (in particular in MICs), programming is usually the responsibility of Ministries of Labour, Social Affairs, Gender or Women and Children. In these circumstances, the focus on food security often, but not always, declines.

However, the picture is not quite as clear cut as the previous paragraph might suggest. There are also many examples of instances where there are numerous programmes at country level, with many different objectives (Box 6) or a single complex programme. Both scenarios require the involvement of many ministries or departments. In these situations, there is a trade-off between keeping the programme located in a specific line (or sector) ministry, and putting the programme in a non-line ministry that co-ordinates the inputs of other line ministries. Each situation has pros and cons and depends on the capacity and willingness to co-ordinate, and the relative power of the ministerial players. In the 2000s in Malawi, the responsibility for social protection moved between a non-line ministry and a line ministry in an attempt to find an appropriate home for social protection. In Ethiopia, the PSNP is located in the Ministry of Agriculture (under the Food Security Directorate), but with links to other parts of the Ministry of Agriculture and other ministries and departments. In Bangladesh, recent recognition that there are a number of programmes run by government departments, NGOs and donors has led to the establishment of a new cross-sectoral working group. It remains to be seen how food security and other objectives will fare under this new arrangement.

The more ways in which a programme seeks to meet food security objectives, the more complex the institutional arrangements required; and different programmes addressing food security require more or less complicated administrative arrangements. PWPs require the involvement of a large number of ministries (agriculture, health, education, transport, lands, natural resources, etc.) if good assets are to be created and maintained that increase food availability and access and improve utilisation. In the case of food and cash programming, although it is frequently assumed that cash is easier to administer than food, there is evidence from Ethiopia that making the transition from food to cash was difficult. Actors in Ethiopia had decades of experience delivering food transfers, but when they switched to cash, they found that, for example, they did not have enough cashiers at woreda (district) level and that they did not have a mechanism for ensuring that cash delivered to woreda level was in the right denominations for delivery to PSNP participants. In 
the case of CCTs, it is widely recognised that tackling only the demand-side or financial barriers to health and education access is not enough. There must be supply-side improvements that involve ministries of health and education. This suggests that it is not sufficient for donors to focus only on social protection programmes that seek to maximise food and nutrition security; they should also look at how they might support better co-ordination across ministries in order to optimise outcomes and achieve greater impact on food security.

The implications of these findings are discussed in the concluding section.

\section{Box 6. Numbers of programmes and institutional arrangements}

Hulme and Maitrot (2011: 3) note that countries that have "multiple small and medium-size social protection programmes face a vast range of different delivery problems and are unlikely to be able to 'solve' all of these problems. If a coherent strategy is developed - focused on one or two large programmes - then the analytical capacity and political will to find solutions to service delivery obstacles is much more likely to be achieved."

They use the Bolsa Familia programme in Brazil as an example: "The successful delivery of this social protection programme requires satisfactory institutional arrangements and co-ordination between ministries and sectors. The conception of a unique social register decreases targeting errors. Also, linking social protection agents with health, education, employment and housing services at state and municipality levels contribute to an effective co-ordination of the programmes and to a more coherent delivery. The success of the Brazilian social protection programme relies on the coherence of its national strategy, through tight co-ordination across all the national social programmes. An integrated and coherent approach to social protection contributes to creating an umbrella social system which improves the efficacy and efficiency of programmes' delivery systems." (Hulme \& Maitrot, 2011: 3).

Underpinning the implementation of social protection programmes with food security objectives are a set of financing challenges. First, funding for social protection and food security programmes is often rarely available (and rarely provided by donors) for long-term programmes. Food transfers, PWPs and some cash transfers are predominantly funded only for short periods of time. This has implications for their impacts. For example, food and cash transfers are far more likely to successfully tackle wasting than stunting. This problem has been compounded by the 2008 food price crisis, which, whilst certainly directing attention to the role of social protection in tackling food security, turned the focus onto social protection for shock response rather than for tackling chronic or seasonal food insecurity. Second, despite the fact that both food security and social protection operate across a range of sectors (rural development, health, education, etc.), donor funding for both tends to be focused on projects rather than on co-ordination and systems. The result is a geographically patchy, unstrategic and poorly co-ordinated set of projects. J oint or pooled funding of national governments' social protection and food security priorities might be one way to tackle this. Related to this is a third challenge, that despite the Rome Declaration, donor funding often remains fragmented and misaligned with government policy and systems. This is a key concern, as it can undermine national ownership of policy processes and further damage weak institutional governance (ODI, 2005). Efforts to harmonise donor funding, to provide an integrated approach with multiple stakeholders, and avoid creating parallel structures or conflicts between donors and government priorities, can be achieved through joint or pooled programme funding mechanisms. Finally, in the context of scarce resources, spending on social protection and food security are often competing with expenditure for other sectors. Donor support through increased official development assistance (ODA) is just one option to support a longer-term and more systematic approach to financing social protection and food security. Other options include considering reallocation, improving efficiency, and potential engagement with non-state actors (Hagen-Zanker $\&$ McCord, 2010). 


\section{Conclusions and way forward}

The analysis presented here shows that social protection can be an effective tool for achieving the goal of food security. The most compelling evidence regards the role that social protection plays in supporting people's access to food, in particular resulting in the consumption of more and/or higher-quality food. Programmes also contribute to improving household livelihoods and food availability by, for example, allowing investments in new productive assets, improving agricultural assets such as land and enhancing access to inputs or markets or credit. Programmes also contribute to improving human capital by enhancing health and education outcomes, and nutrition outcomes have been improved by social protection programmes in many countries, the most notable impacts being large reductions in stunting and wasting, and significant increases in height-for-age expected at adulthood.

Despite the successes of many programmes, social protection programmes do not always deliver improvements in food security. There are a number of reasons for this.

First, getting the design right is critical. Short-term programmes with small or unpredictable payments are far less likely to enhance food availability and access, or nutrition. Examples include food transfers made in PWPs that have energy (calorific) values lower than the amount of energy exerted during work activities, and cash transfers whose real value is diminished by inflation or food price shocks, or which are delivered at the wrong time of year to support agricultural production for own consumption.

Second, achieving lasting change takes time. Substantial and sustained impacts are not possible when projects and programmes have only short time lines. This is particularly true of PWPS, where, too often, programmes provide only short-term, periodic employment of a month or so. P rogrammes that demonstrate the most substantial effects on food security are those that run for decades, not years or months. Social protection programmes can certainly contribute to shock response, but they can only buffer households against emerging shocks if they are already in place.

Third, food security is a complex challenge involving many different agencies and actions. Too often, agencies deal with this complexity by incorporating too many objectives into a single programme, rather than working in a co-ordinated and cross-sectoral way. Social protection instruments are relatively blunt instruments. Some programmes are able to have an impact on access, availability and nutrition simultaneously. For example, in Bolivia, programme beneficiaries increased their food consumption by $165 \%$ of the value of the transfer, because they invested in agricultural production that generated more food and income than the transfer itself. It is usually better, however, not to load individual programmes or projects with too many objectives, but rather to prioritise one specific objective and then design the programme so that other positive overspill effects can be optimised. Mechanisms to enable this to happen include establishing and institutionalising co-ordination mechanisms such as cross-sectoral working groups between relevant donors, ministries (at national and local levels) and non-governmental organisations. Key actors may include, for instance, UNICEF, WFP, FAO, ILO, the Deutsche Gesellschaft fur Internationale Zusammenarbeit (GIZ), Ministries of Agriculture, Food Security, Rural Development, Labour, Social Affairs, Gender, Women and Children, and non-governmental organisations (NGOs) such as Oxfam, Action Against Hunger and Concern Worldwide. Attempting to tackle access, availability and utilisation might be possible in well-resourced programmes, but caution is advised before attaching objectives related to other economic and social vulnerabilities (such as achieving social cohesion, improving state-citizen compacts or reducing gender-based violence). A do-no-harm principle would work better in this case.

Fourth, combining different objectives, either within food security (access, availability and nutrition) or beyond (social cohesion, rights, security, climate change adaptation) demands navigating a 
series of trade-offs. The starkest example of this is related to public works, where there is a need to prioritise either the welfare function of public works or the asset creation function. Creating assets efficiently and effectively requires a higher level of planning and expenditure on capital assets (machinery) and staff (engineers), which reduces the amount of programme funding available for wage transfers. Frequently, attempts to navigate this trade-off result in a sub-optimal scenario where the quality of public works is very poor. In trying to meet two objectives, we end up meeting neither particularly well. Other trade-offs relate to the breadth of programmes versus depth of support. In LICS, where poverty rates are highest, few governments can afford to provide social protection to all poor people and simultaneously transfer enough cash or food to have a meaningful impact on their food security.

There are a number of actions that could contribute to overcoming some of these challenges. These include:

1. Ensuring a focus on chronic and seasonal food security, not just shocks. Whilst the 2008 global food price shock certainly increased the profile of social protection in tackling food insecurity, social protection is far better placed to tackle chronic and seasonal hunger than sudden shocks. It is widely recognised that buffering people against future shocks is cheaper than responding after a shock.

2. Starting design processes with (a small number of) clear and realistic food security objectives for social protection programmes and work on a "do no harm" principle when it comes to broader objectives or impacts. This means avoiding loading up social protection with too many objectives and expectations.

3. Monitoring impacts of programmes on food security outcomes more robustly, for example, by using baselines and finding ways to attribute outcomes to programmes. As noted above, in many programmes, there is scope to strengthen monitoring and improve learning. For donor agencies that have less direct food security objectives, it is still worth monitoring against food security indicators to help generate more evidence about what works and to help donors understand the linkages between their various objectives and outcomes.

4. Being explicit about time frames and the effort that will be required. It is advisable to avoid overselling the contribution of social protection to food security and oversimplifying the problem. Many food security challenges are structural and result from economic and natural systems that are difficult to change. There is a persuasive story to tell about the importance of social protection in tackling the often complex issues of food and nutrition insecurity, and there are many good examples of successful programmes. To achieve this necessitates a long-term perspective, requiring long-term commitments from donors in terms of financing and also in supporting the establishment of national systems and institutions.

5. Being explicit about the other things that need to happen, beyond social protection programmes, in order for food security outcomes to be improved. Examples include actions in the agriculture, health, education and trade sectors.

6. Establishing more (effective) co-ordination mechanisms both within and across individual agencies (so that social protection and food security speak to each other and perhaps to other sectors). Whilst both social protection and food security are multi-sectoral in nature, and they do need institutional homes in donor agencies, they do not need to be siloed. A review of donor agency systems for co-ordination, sharing objectives, joint planning and design, etc., could identify examples of good (and less good) practice.

7. Strengthening the design logic of programming (in both national governments and internally across their own country strategies) to ensure that linkages between social protection 
and sectors contributing to food security (agriculture, rural development, health, education) are clearly articulated.

8. Generating more practical guidance on navigating these trade-offs and policy choices. Where donors seek to use social protection to tackle food and nutrition insecurity, they will face numerous choices in policy development and programme selection and design. For example, to make an informed choice between cash and food instruments, programmers need to know how well local food markets work, so they can assess whether cash might push up prices locally. Often, however, there is no clear package of resources that maps out what programmers need to know and how they get access to that information. One route for achieving this could be an on-line toolbox and key sheets that provide the basis for a community of practice and knowledge-sharing for people working on social protection and food security. 


\section{Bibliography}

Adger, N. W., Dessai, S., Goulden, M., Hulme, M., Lorenzoni, I., Nelson, D. R., Naess, L. O., Wolf, J. \& W reford, A. (2009), Are there social limits to adaptation to climate change? Climatic Change, No. 93, pp. 335-354.

Adato, M. and Bassett, L. (2008), "What is the potential of cash transfers to strengthen families affected by HIV and AIDS? A review of the evidence on impacts and key policy debates." Submitted to the J oint Learning Initiative on Children and AIDS (J LICA). Washington DC: International Food Policy Research Institute (IFPRI).

Adelman, S., Gilligan, D., Konde-Lule, J. and Alderman, H. (2012), "School feeding reduces anemia prevalence in adolescent girls and other vulnerable household members in a cluster randomized controlled trial in Uganda. Washington DC: International Food Policy Research Institute. Cited in: HLPE (2012), Social protection for food security. A report by the High Level Panel of Experts on Food Security and Nutrition of the Committee on World Food Security, Rome 2012.

Adu-Afarwuah, S., Lartey, A., Brown, K., Zlotkin, S., Briend, A. and Dewey, K. (2007), "Randomized comparison of three types of micronutrient supplements for home fortification of complementary foods in G hana: Effects on growth and motor development", American Journal of Clinical Nutrition 86: 412-420. Cited in: HLPE (2012), Social protection for food security. A report by the High Level Panel of Experts on Food Security and Nutrition of the Committee on World Food Security, Rome 2012.

Aguero, J., Carter, M. and Woolard, I. (2007). "The impact of unconditional transfers on nutrition: the South African Child Support Grant". Brasilia: International Poverty Centre. Cited in: HLPE (2012), "Social protection for food security. A report by the High Level Panel of Experts on Food Security and Nutrition of the Committee on World Food Security", Rome 2012.

Ahmed, A. (2004), "Impact of feeding children in school: Evidence from Bangladesh". Washington DC: International Food Policy Research Institute. Cited in: HLPE (2012), Social protection for food security. A report by the High Level Panel of Experts on Food Security and Nutrition of the Committee on World Food Security, Rome 2012.

Ahmed, A., Quisumbing, A., Nasreen, M., Hoddinott, J . and Bryan, E. (2010b). Comparing food and cash transfers to the ultra-poor in Bangladesh, IFPRI Research Monograph 163. Washington DC: International Food Policy Research Institute. Cited in: HLPE (2012), Social protection for food security. A report by the High Level Panel of Experts on Food Security and Nutrition of the Committee on W orld Food Security, Rome 2012.

Attanasio, 0. and Mesnard, A. (2006), "The impact of a conditional cash transfer programme on consumption in Colombia." Fiscal Studies 27(4): 421-42.

AusAID (2012), Social Protection Framework, J une 2012. Australian Government, Canberra.

Bailey, S. and Hedlund, K. (2012), The impact of cash transfers on nutrition in emergency and transitional contexts: A review of the evidence. Humanitarian Policy Group. London: ODI.

Bardhan, P. and Mookherjee, D. (2011), Subsidized Farm Input Programs and Agricultural Performance: A Farm-Level Analysis of West Bengal's Green Revolution, 1982-1995, American Economic Journal: Applied Economics 3(4): 186-214. Cited in: HLPE (2012), Social protection 
for food security. A report by the High Level Panel of Experts on Food Security and Nutrition of the Committee on W orld Food Security, Rome 2012.

Barrientos, A. and Scott, J . (2008), "Social transfers and growth: A review." BWPI Working Paper 52. Manchester: Brooks World Poverty Institute.

Behrman, J. and Hoddinott, J. (2005), "Program evaluation with unobserved heterogeneity and selective implementation: The Mexican Progresa impact on child nutrition." Oxford Bulletin of Economics and Statistics 67: 547-569.

Berhane, G., Hoddinott, J ., Kumar, N., Taffesse, A., Diressie, M., Yohannes, Y., Sabates-W heeler, R., Handino, M., Lind, J., Tefera, M. and Simma, F. (2012), Evaluation of Ethiopia's Food Security Program: Documenting progress in the implementation of the Productive Safety Nets Programme and the Household Asset Building Programme. Washington DC: International Food Policy Research Institute. Cited in: HLPE (2012), Social protection for food security. A report by the High Level Panel of Experts on Food Security and Nutrition of the Committee on World Food Security, Rome 2012.

BMZ (2009), Sector Strategy on Social Protection, Strategies 190. German Federal Ministry for Economic Cooperation and Development (BMZ), Bonn/Berlin.

BMZ (2011), Rural development and its contribution to food security. BMZ Strategy Paper 1. German Federal Ministry for E conomic Cooperation and Development (BMZ), Bonn/Berlin.

Breisinger, C., van Rheenen, T., Ringler, C., Nin Pratt, A., Minot, N., Aragon, C., Yu, B., Ecker, O. and Zhu, T. (2010), Food security and economic development in the Middle East and North Africa: Current state and future perspectives, Discussion Paper 00985. Washington DC: International Food Policy Research Institute. Cited in: HLPE (2012), Social protection for food security. A report by the High Level Panel of Experts on Food Security and Nutrition of the Committee on World Food Security, Rome 2012.

Coles (forthcoming), What is known about the impact of structured demand activities on resilient food systems? London: ODI.

Conroy, K. (2008), IEP impact: Coping strategies of IEP and non-IEP households during monga. Presentation. CLP.

Council of the European Union (2010), Council conclusions on an EU policy framework to assist developing countries in addressing food security challenges. Council of the European Union, 3011th Foreign Affairs Council meeting, Brussels, 10 May 2010.

Dandekar, K. (1983), Employment Guarantee Scheme: Employment opportunities for women. Pune: Gokhle Institute of Politics and Economics. Cited in: HLPE (2012), Social protection for food security. A report by the High Level Panel of Experts on Food Security and Nutrition of the Committee on World Food S ecurity, Rome 2012.

Devereux, S. (2002), Can social safety nets reduce chronic poverty? Development Policy Review 20(5): 657-675. Cited in: HLPE (2012), Social protection for food security. A report by the High Level Panel of Experts on Food Security and Nutrition of the Committee on World Food Security, Rome 2012.

Devereux, S. and Sabates-Wheeler, R. (2004), Transformative social protection, IDS Working Paper 232. Institute of Development Studies (IDS), B righton.

DFID (2011), Cash Transfers Evidence Paper Policy Division 2011. UK Department for International Development (DFID), London. 
DFID Bangladesh (2006), Challenging the Frontiers of Poverty Reduction: Specially Targeted Ultra Poor P rogramme, Project Completion R eport, September 2006, DFID, Dhaka.

Dorward, A., Chirwa, E., Boughton, D., Crawford, E., J ayne, T., Slater, R., Kelly, V. and Tsoka, M. (2008). Towards "smart" subsidies in agriculture? Lessons from recent experience in Malawi, ODI Natural Resource Perspectives 116. London: ODI. Cited in: HLPE (2012), Social protection for food security. A report by the High Level Panel of Experts on Food Security and Nutrition of the Committee on W orld Food Security, Rome 2012.

Ecker, O. and Breisinger, C. (2012), "The food security system: A new conceptual framework." IFPRI Discussion Paper 01166.

EPRI (2011), "Designing and implementing social transfer programmes". Cape Town: Economic Policy R esearch Institute.

European Commission (2012), Social Protection in European Union Development Cooperation: Communication from the Commission to the European Parliament, the Council, the European Economic and Social Committee and the Committee of the Regions. European Commission, Brussels.

FAO (1996), Rome Declaration on World Food Security and World Food Summit Plan of Action. FAO, Rome.

Farrington, J . (2010), "Risk, vulnerability and social protection: Concepts, issues and evidence." Regional conference on sustainable livelihoods and rural development - "Two decades of impact and learning." 21-23 April 2010, Delhi, India: DFID.

Fay, M., Leipziger, D., Wodon, Q. and Yepes, T. (2005), "Achieving child health-related Millennium Development Goals: The role of infrastructure." World Development 33(8): 1267-1248.

Ferguson, H. and Kepe, T. (2011), Smallholder farmer participation in local and regional food aid procurement: Assessing the benefits and challenges in southwestern Uganda. International Development Planning Review 33 (IDPR). Cited in: Coles (forthcoming), What is known about the impact of structured demand activities on resilient food systems? London: ODI.

Fiszbein, A. and Schady, N. (2009), Conditional Cash Transfers. Washington, DC: World Bank.

Fiszbein, A. and Schady, N. (2009), Conditional Cash Transfers: Reducing Present and Future Poverty. A World Bank Policy Research Report. Washington, DC: World Bank.

Freeland, N. and Cherrier, C. (2012), Social transfers in the fight against hunger: A resource for development practitioners. EuropAid Tools and Methods Series. European Commission.

Frongillo, E. A. J r., de Onis, M. and Hanson, K. M. (1997), "Socioeconomic and demographic factors are associated with worldwide patterns of stunting and wasting of children." J ournal of Nutrition 127(12): 2302-2309.

Gertler, P., Martínez, S. and M. Rubio-Codina (2006), "Investing Cash Transfers to Raise LongTerm Living Standards." Policy Research Working Paper 3994. Washington, DC: World Bank.

Goto, R. and Mascie-Taylor, N. (2010), CLP Nutrition Surveys - Cross-sectional analysis of Round 4 and Longitudinal analyses in nutritional status over rounds 1 to 4. Government of Bangladesh, DFID and Maxwell Stamp.

Government of Ireland (2006), White Paper on Irish Aid. Government of Ireland, Dublin. 
Hagen-Zanker, J. and McCord, A. with Ellis, K., Hedger, E., Moon, S. and R. Singh (2010), Financing Social Protection in the Light of International Spending Targets: A Public Sector Spending Review. ODI Report, London.

Harrigan, J . (2005), "Food insecurity, poverty and the Malawian Starter Pack: Fresh start or false start?" Paper presented at the Social Protection for Chronic Poverty Conference, Manchester, 23-24 February 2005.

Hashemi, S. M. and Umaira, W. (2011), "New pathways for the poorest: the graduation model from BRAC." CSP Research Report 10, Brighton: IDS.

HLPE (2012), Social protection for food security. A report by the High Level Panel of Experts on Food Security and Nutrition of the Committee on World Food Security, Rome 2012.

Hoddinott, J. (2008), Nutrition and Conditional Cash Transfer (CCT) Programs. Unpublished manuscript, International Food Policy Research Institute, Washington, DC. Cited in Fiszbein, A. and Schady, N. (2009), Conditional Cash Transfers: Reducing Present and Future Poverty. A World Bank Policy Research Report. Washington, DC: World Bank.

Hoddinott, J ., Skoufias, E. and Washburn, R. (2000), "The impact of PROGRESA on consumption: A final report." Washington, DC: International Food Policy Research Institute.

Hulme D. and M. Maitrot (2011), Scaling-up Social Protection in Bangladesh: Building Effective Social Ladders and Safety Nets. UNDP Dhaka October 2011.

IFAD, FAO and WFP (2012), The State of Food Insecurity in the World 2012. Economic growth is necessary but not sufficient to accelerate reduction of hunger and malnutrition. R ome, FAO.

J acoby, H. (2002), Is there an intrahousehold 'flypaper effect'? Evidence from a school feeding programme, Economic J ournal 112: 196-221. Cited in: HLPE (2012), Social protection for food security. A report by the High Level Panel of Experts on Food Security and Nutrition of the Committee on World Food S ecurity, Rome 2012.

Jalan, J . and M. Ravallion (2003), "Estimating the benefit incidence of an antipoverty program by propensity-score matching". Journal of Business \& Economic Statistics 21(1): 19-30. Cited in: McCord A. (forthcoming), Public Works and Resilient Food Systems. London: ODI.

JICA (2011), Inclusive and Dynamic Development, Annual Report 2011. Japan International Cooperation Agency (J ICA), Tokyo.

Kazianga, H., de Walque, D., and Alderman, H. (2009), Educational and Health Impact of Two School Feeding Schemes: Evidence from a Randomized Trial in Rural Burkina Faso. Working Paper, Washington, DC, The World Bank. Cited in: Coles (forthcoming), What is known about the impact of structured demand activities on resilient food systems? London: ODI.

Kebede, E. (2006), "Moving from emergency food aid to predictable cash transfers: recent experience in Ethiopia." Development Policy Review, 24(5): 579-599.

Lin, C., Manary, M., Maleta, K., Briend, A. and Ashorn, P. (2008), An energy-dense complementary food is associated with a modest increase in weight gain when compared with a fortified porridge in Malawian children aged 6-18 months, Journal of Nutrition 138: 593-598. Cited in: HLPE (2012), Social protection for food security. A report by the High Level Panel of Experts on Food Security and Nutrition of the Committee on World Food Security, Rome 2012.

Lutter, C., Rodrıguez, A., Fuenmayor, G., Avila, L., Sempertegui, F. and Escobar, J. (2008), Growth and micronutrient status in children receiving a fortified complementary food, J ournal of 
Nutrition 138(2): 379-388. Cited in: HLPE (2012), Social protection for food security. A report by the High Level Panel of Experts on Food Security and Nutrition of the Committee on World Food Security, Rome 2012.

Macours, K., Schady, N. and Vakis, R. (2008), "Cash transfers, behavioral changes, and the cognitive development of young children: evidence from a randomized experiment." Policy Research W orking Paper 4759. Washington, DC: World Bank

Maluccio, J. (2008), "The Impact of Conditional Cash Transfers in Nicaragua on Consumption, Productive Investments, and Labor Allocation."J ournal of Development Studies.

Maluccio, J. A., and Flores, R. (2005), "Impact evaluation of a conditional cash transfer program: The Nicaraguan Red de Protección Social." IFPRI Research Report 141. Washington, DC: International Food Policy Research Institute.

Maluccio, J., Hoddinott, J., Behrman, J., Martorell, R., Quisumbing, A. and Stein, A. (2009), The impact of nutrition during early childhood on education among Guatemalan adults, Economic J ournal 119 (April): 734-763. Cited in: HLPE (2012), Social protection for food security. A report by the High Level Panel of Experts on Food Security and Nutrition of the Committee on World Food Security, Rome 2012.

Maluccio, J., Murphy, A. and Regalía, F. (2006), Does Supply Matter? Initial Supply Conditions and the Effectiveness of Conditional Cash Transfers for Grade Progression in Nicaragua." Unpublished manuscript, Inter-American Development Bank, Washington, DC. Cited in Fiszbein, A. and Schady, N. (2009), Conditional Cash Transfers: Reducing Present and F uture Poverty. A World Bank Policy Research Report. Washington, DC: The World Bank.

Marks, M. and Vignon, C. (2009), "Char life, livelihoods, and development in floodplain Bangladesh." in Zaman, M., Elahi, K. M. and Khatun, H. (eds.), Disasters, development and resettlement in Bangladesh: Issues, people and policies (DRAFT).

Martinez, S. (2007), "Invertir el Bonosol para aliviar la pobreza: Retornos económicos en los hogares Beneficiaries." in Aponte, G., Jemio, L. C., Laserna, R., Martinez, S., Molina, F., Schulze, E. and Skinner E. (eds.), La Inversión Prudente. Impacto del Bonosol sobre la familia, la equidad social y el crecimiento económico. La Paz, Brazil: Agosto.

Mascie-Taylor, N. (2010), Chars Livelihoods Programme: Comparison of the socio-economic characteristics and nutritional status of households recruited in the previous CLP Programme (CLP1) with the newly recruited households in CLP2 (CLP2.1).

McCord, A. (2012), Public Works and Social Protection in sub-Saharan Africa: Public Works Work for the Poor? Cape Town/Tokyo: J uta Press/UNU.

McCord, A. (forthcoming), Public Works and Resilient Food Systems. London: ODI.

Miller, C., Tsoka, M. and Reichert, K. (2011), Impacts on children of cash transfers in Malawi, chapter 6 in Handa, S., Devereux, S and Webb, D. (editors), Social Protection for Africa's Children. London: Routledge. Cited in: HLPE (2012), Social protection for food security. A report by the High Level Panel of Experts on Food Security and Nutrition of the Committee on World Food Security, Rome 2012.

Ministry of Community Development and Social Services \& German Technical Cooperation (MCDSS and GTZ) (2006), Evaluation report: Kalomo Social Cash Transfer Scheme. Lusaka: MCDSS. 
Minot, N. and Benson, T. (2009), Fertilizer subsidies in Africa, Issue Brief 60. Washington DC: International Food Policy Research Institute. Cited in: HLPE (2012), Social protection for food security. A report by the High Level Panel of Experts on Food Security and Nutrition of the Committee on World Food S ecurity, Rome 2012.

Neufeld, L., Sotres Alvarez, D., Gertler, P., Tolentino Mayo, L., J imanez Ruiz, J ., Fernald, L., Villalpando, S., Shamah, T. and Rivera Dommarco, J . (2005), "Impacto de Oportunidades en el Crecimiento y Estado Nutricional de Niños en Zonas Rurales." In Evaluación Externa de Impacto del Programa Oportunidades 2004: Alimentación, ed. Bernardo Hernández Prado and Mauricio Hernández Ávila. Cuernavaca, Morales, México: Instituto Nacional de Salud Pública.

ODI (Overseas Development Institute) (2005), Harmonisation and Alignment in Fragile States. DAC Learning and Advisory Process on Difficult Partnerships. Senior-level Forum on Development Effectiveness in Fragile States, London, United Kingdom, 13-14 J anuary 2005

Otsuki, K. and Arce, A. (2007), Brazil: A desk review of the National School Feeding Programme, mimeo. Wageningen: Department of Social Sciences, Wageningen University. Cited in: HLPE (2012), Social protection for food security. A report by the High Level Panel of Experts on Food Security and Nutrition of the Committee on World Food Security, Rome 2012.

Pinstrup-Andersen, P. (1988), Food subsidies in developing countries: Costs, benefits and policy options. Baltimore: J ohns Hopkins University Press. Cited in: HLPE (2012), Social protection for food security. A report by the High Level Panel of Experts on Food Security and Nutrition of the Committee on World Food S ecurity, Rome 2012.

Pinstrup-Andersen, P. (2009), "Food security: Definition and measurement." Food Security 1(1): 57.

Rabbani, M., Prakash, V. A., and Sulaiman, M. (2006), "Impact assessment of CFPR/TUP: A descriptive analysis based on 2002-2005 panel data." CFPR/TUP Working Paper Series 12. Dhaka: BRAC.

Rao, C., Ray, S. and Subbarao, K. (1988), Unstable agriculture and droughts: Implications for policy. Delhi: Vikas. Cited in: HLPE (2012), Social protection for food security. A report by the High Level Panel of Experts on Food Security and Nutrition of the Committee on World Food Security, Rome 2012.

Reid, P. (2010), "Land-based productivity; impact and learning from DFID projects." Regional conference on sustainable livelihoods and rural development - "Two decades of impact and learning." 21-23 April 2010, Delhi, India: DFID.

Rivera, J . A., Sotres-Álvarez, D., Habicht, J .-P., Shamah, T. and Villalpando, S. (2004), "Impact of the Mexican program for education, health, and nutrition (PROGRESA) on rates of growth and anemia in infants and young children: A randomized effectiveness study." J ournal of the American Medical Association 291(21): 2563-70.

Ruel, M., Menon, P., Habicht, J-P., Loechl, C., Bergeron, G., Pelto, G., Arimond, M., Maluccio, J ., Michaud, L. and Hankebo, B. (2008), Age-based preventive targeting of food assistance and behaviour change and communication for reduction of childhood undernutrition in Haiti: A cluster randomised trial, The Lancet 371: 588-595. Cited in: HLPE (2012), Social protection for food security. A report by the High Level Panel of Experts on Food Security and Nutrition of the Committee on World Food Security, Rome 2012.

Sadoulet, E., de J anvry, A. and Davis, B. (2001), "Cash transfers programs with income multipliers: Procampo in Mexico." FCND Discussion Paper 99. 
Samson, M. et al. (2007), The social and economic impact of cash transfers. Economic Policy Research Institute, Commissioned for DFID.

Schroeder, D., Martorell, R., Rivera, J., Ruel, M. and Habicht, J -P. (1995), Age differences in the impact of nutritional supplementation on growth, J ournal of Nutrition 125(4S): 1051S-1059S. Cited in: HLPE (2012), Social protection for food security. A report by the High Level Panel of Experts on Food Security and Nutrition of the Committee on World Food Security, Rome 2012.

Sguassero, Y., de Onis, M. and Carroli, G. (2005), Community-based supplementary feeding for promoting the growth of young children in developing countries, Cochrane Database of Systematic Reviews 2005, Issue 4. Art. No.: CD005039. DOI: 10.1002/14651858.CD005039.pub2. Cited in: HLPE (2012), Social protection for food security. A report by the High Level Panel of Experts on Food Security and Nutrition of the Committee on World Food Security, Rome 2012.

S mith, L. C., Ruel, M. T. and Ndiaye, A. (2005), "Why is child malnutrition lower in urban than in rural areas? Evidence from 36 developing countries." W orld Development 33(8): 1285-1305.

Sumberg, J. and Sabates-Wheeler, R. (2010), Linking Agricultural Development to School Feeding. Working paper. Brighton, Institute of Development S tudies.

USDA (2009), The Use of Local and Regional Procurement in Meeting the Food Needs of Those Affected by Disasters and Food Crises. Washington, DC, United States Department of Agriculture. Cited in: Coles (forthcoming), What is known about the impact of structured demand activities on resilient food systems? London: ODI.

Vincent, K. and Cull, T. (2009), Impacts of social cash transfers: case study evidence across southern Africa. Instituto de Estudos Sociais e Económicos.

Webb, P. (1995), E mployment programs for food security in rural and urban Africa: Experiences in Niger and Zimbabwe, chapter 7 in von Braun, J . (editor) Employment for Poverty Reduction and Food Security. Washington DC: International Food Policy Research Institute. Cited in: HLPE (2012), Social protection for food security. A report by the High Level Panel of Experts on Food Security and Nutrition of the Committee on World Food S ecurity, Rome 2012.

WFP (2012), 'Update of WFP's safety nets policy: Consultation Document': World Food Programme, Rome.

World Bank (2012), Resilience, Equity and Opportunity, The World Bank 2012-2022 Social Protection And Labor Strategy. Washington, DC: The World Bank.

World Summit on Food Security (2012), Declaration of the World Summit on Food Security, Rome 16-18 November 2009.

Yablonski, J . and O'Donnell, M. (2009), Lasting benefits: the role of cash transfers in tackling child mortality. London: Save the Children. 


\section{Annex 1. Agency linkages between social protection and food security}

Table 1. Bilateral and multilateral agency and IFI linkages between social protection and food security

\begin{tabular}{|c|c|c|}
\hline & $\begin{array}{l}\text { How is the linkage between social protection and food security } \\
\text { articulated? }\end{array}$ & $\begin{array}{l}\text { How does this articulation of linkages translate into } \\
\text { programming? }\end{array}$ \\
\hline$\frac{9}{\frac{1}{c}}$ & $\begin{array}{l}\text { AusAID's approach to social protection is heavily embedded in food security objectives. } \\
\text { Improving food and nutrition security is one of three pillars in its social protection } \\
\text { framework. The other two are reducing the financial barriers to accessing education } \\
\text { and health services. Because AusAID has strong bilateral aid arrangements with a } \\
\text { number of MICs, the focus on food security is as much on improving nutrition as it is on } \\
\text { meeting basic calorific requirements. In AusAID's broader rural development strategy, } \\
\text { social protection is one of three pillars, alongside agricultural research and improving } \\
\text { rural and agricultural markets. }\end{array}$ & $\begin{array}{l}\text { AusAID programming largely reflects the three pillars of its framework. } \\
\text { The main contrast for AusAID is geographic. In Southeast Asia and the } \\
\text { Pacific, most programming (in particular in MICs) focuses on tackling } \\
\text { financial barriers to education and health service access. Examples } \\
\text { include support to CCTs in Indonesia and the Philippines, and } \\
\text { programmes to subsidise transport to enhance access to education in Fiji. } \\
\text { In South Asia and Africa, the focus is more directly on tackling food } \\
\text { insecurity by maintaining consumption and supporting productive } \\
\text { capacity. Examples of the latter include investments in the CLP in } \\
\text { Bangladesh, the PRP in Zimbabwe and inputs to the Hunger Safety Net } \\
\text { Programme (HSNP) in Kenya. }\end{array}$ \\
\hline 号 & $\begin{array}{l}\text { DFID finds that cash transfers specifically (rather than social protection more broadly) } \\
\text { lead to three specific outcomes: better education status; better health status; and } \\
\text { better food security and nutrition. The most recent policy-type documents from DFID } \\
\text { are relatively old. In its Agriculture Policy Paper (2005), the focus is on ensuring that } \\
\text { social protection programmes are complementary to growth in agriculture: as well as } \\
\text { providing basic consumption support, they should also support investments in } \\
\text { productive activities and use instruments such as cash to stimulate rather than disrupt } \\
\text { local markets. }\end{array}$ & $\begin{array}{l}\text { Food security is a major objective of DFID social protection programming: } \\
\text { E.g. CLP in Bangladesh, Ethiopia's PSNP; Kenya's HSNP; Ghana's LEAP; } \\
\text { Uganda's ESP; Zimbabwe's PRP. }\end{array}$ \\
\hline$\vec{u}$ & $\begin{array}{l}\text { The EU communication on Social Protection in European Union Development } \\
\text { Co-operation focuses on the role of social protection in contributing to inclusive } \\
\text { growth. Social protection sits within a thematic group including employment and social } \\
\text { inclusion, and activities appear to be focused on labour-related risks. Food security is } \\
\text { not mentioned explicitly or directly, although there are frequent mentions of the role } \\
\text { of social protection in contributing to poverty reduction and supporting households in } \\
\text { the face of global food price shocks. The EU aligns itself strongly with the ILO's Social } \\
\text { Protection Floor. Rural development policy in developing countries is focused on } \\
\text { broad-based economic market and development and rural non-farm activities, } \\
\text { equitable and secure land access, and agricultural research, while social protection } \\
\text { plays only a small role under "addressing risk and vulnerability". }\end{array}$ & $\begin{array}{l}\text { The latest policy statements from the EU on social protection do not } \\
\text { prioritise particular instruments. Activities are heavily focused on } \\
\text { supporting the establishment of national systems rather than funding or } \\
\text { support for specific instruments. }\end{array}$ \\
\hline
\end{tabular}




\begin{tabular}{|c|c|c|}
\hline 원 & $\begin{array}{l}\text { There is no explicit policy statement on social protection by the FAO. Much of its work } \\
\text { on social protection follows a research and evidence-building agenda, particular in } \\
\text { relation to agricultural growth. FAO does work on inputs transfers and subsidies, but } \\
\text { this is largely in relation to increasing agricultural productivity or livelihoods recovery } \\
\text { and not in relation to social protection. }\end{array}$ & $\begin{array}{l}\text { FAO is not a grant or transfer-making agency in relation to social } \\
\text { protection and food security, though it does provide critical support to } \\
\text { safety-net systems for food security, for example through Crop Food } \\
\text { Security and Assessment Missions (CFSAMs) at national level and other } \\
\text { critical monitoring and vulnerability mapping activities. }\end{array}$ \\
\hline$\frac{N}{\mathrm{U}}$ & $\begin{array}{l}\text { In its formal documentation, for example GIZ's Sector Strategy on Social Protection, } \\
\text { the focus is on rights, tackling life-cycle risks (including chronic illness), investing in the } \\
\text { health and education of household members and using social protection to contribute } \\
\text { to social justice and help to maintain stability and peace. Food security is mentioned } \\
\text { only once, although protecting people in the rural sector is acknowledged (for example } \\
\text { the need to protect households against crop failure) but these connections (in formal } \\
\text { documentation at least) are implicit rather than explicit. } \\
\text { In GIZ's rural development strategy, the focus of social security is articulated as a } \\
\text { combination of enhancing access to other social services and access to food: "Social } \\
\text { security systems ... can ensure not only access to health facilities but also access to } \\
\text { food." The focus is on social transfers, community-based insurance and school feeding } \\
\text { programmes. }\end{array}$ & $\begin{array}{l}\text { GIZ's core social protection outlined in its sector strategy is diverse: social } \\
\text { health protection, old-age security, persons with disabilities, protection } \\
\text { against natural disasters and crop failure risks, social policy, systemic } \\
\text { advice, micro-insurance and basic social protection programming. Some } \\
\text { operations do make transfers to food insecure people, though the links to } \\
\text { food security are not made explicitly in programming summaries. Other } \\
\text { operations are at a different level, for example those that seek to } \\
\text { improve the fiscal, legal and institutional frameworks and coherent } \\
\text { design of comprehensive social protection programmes. The KfW } \\
\text { development bank also provides support to a number of cash transfer } \\
\text { programmes, including the Malawi Social Cash Transfer Programme. }\end{array}$ \\
\hline 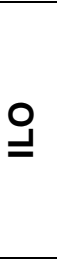 & $\begin{array}{l}\text { The main focus of ILO's social protection work is the promotion of a minimum } \\
\text { guarantee through the social protection floor. The social protection floor is heavily } \\
\text { focused on life-cycle/idiosyncratic risks and wider access to services. There is little } \\
\text { focus on transient food security issues and shocks that might be covariant. The social } \\
\text { protection floor does promote employment insurance or guarantees, but this is not } \\
\text { specifically focused on food security. }\end{array}$ & $\begin{array}{l}\text { ILO's social protection work sits within the social security department and } \\
\text { is mainly focused on technical co-operation for policy analysis and design. } \\
\text { Globally, it works to secure international agreements on social protection } \\
\text { approaches and spending. In recent years, a major focus of its analysis in } \\
\text { developing countries has been the completion of social protection } \\
\text { expenditure and performance reviews. }\end{array}$ \\
\hline 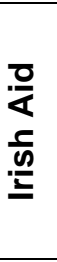 & $\begin{array}{l}\text { Irish Aid's white paper (2006) embeds social protection within its humanitarian and } \\
\text { food security themes, and maintains strong links to agriculture and rural development. } \\
\text { Social protection is viewed as a key component of Disaster Risk Reduction, and much } \\
\text { programming focuses on directly tackling food insecurity. At a strategic level, the } \\
\text { agency is committed to providing social protection and building productive capacity, } \\
\text { but it seeks to build productive capacity in ways rather different from the World Bank. }\end{array}$ & $\begin{array}{l}\text { Examples of programming include supporting Malawi's Agricultural } \\
\text { Inputs Supply Programme, which suggests that Irish Aid views agricultural } \\
\text { inputs transfers or subsidies as overlapping with social protection } \\
\text { programmes. At the same time, it does engage with broader national } \\
\text { social protection strategy processes, for example in Mozambique, where } \\
\text { its focus is on support to vulnerable children. }\end{array}$ \\
\hline$\frac{\pi}{S}$ & $\begin{array}{l}\text { Social protection and food security are relatively distinct components of Japan } \\
\text { International Co-operation Agency (JICA) programming. Its approach to social } \\
\text { protection is aligned with a social security approach, with a focus on two elements: } \\
\text { social insurance and social welfare. Food security is the overarching narrative for work } \\
\text { on agriculture and rural development, and few linkages are made between the two. }\end{array}$ & $\begin{array}{l}\text { Activities to tackle food insecurity are focused on: i) sustainable } \\
\text { agricultural production, ii) stable food supply, and iii) promoting vitality in } \\
\text { rural areas. Activities under social security have the potential to have } \\
\text { indirect impact on food security, for example medical insurance and } \\
\text { pensions, and programmes to support the elderly, children and mothers. }\end{array}$ \\
\hline
\end{tabular}




\begin{tabular}{|c|c|c|}
\hline$\frac{0}{4}$ & $\begin{array}{l}\text { WFP tends to focus on "safety nets" rather than social protection, but notes the } \\
\text { significant overlaps between the two terms. In its updated statement of WFP's role, it } \\
\text { notes that WFP investments in safety nets are explicitly focused on food assistance for } \\
\text { food and nutrition, rather than broader objectives of safety nets, such as general } \\
\text { poverty reduction or income-support goals. WFP explicitly acknowledges that } \\
\text { entitlements to food are not solely achieved by food transfers or food purchase, and so } \\
\text { recognises the role that cash transfers can play in supporting food security. However, } \\
\text { the extent to which it will pursue cash transfers or cash-for-work programmes remains } \\
\text { a debated issue within the agency. }\end{array}$ & $\begin{array}{l}\text { WFP classifies some of its activities as safety-net "instruments" or } \\
\text { "transfers" - such as cash/food for work, and school feeding - and others } \\
\text { as "functions in support" of safety nets. The latter may include } \\
\text { cross-cutting services such as vulnerability analysis and mapping (VAM), } \\
\text { procurement or logistics, which inform and support the implementation } \\
\text { of instruments. Similarly, food reserves supply locally procured food to } \\
\text { support safety-net programmes. Initiatives such as Purchase for Progress } \\
\text { (P4P), when integrated into social protection strategies, as in Brazil, can } \\
\text { reinforce safety-net systems. }\end{array}$ \\
\hline
\end{tabular}

Source: Government of Ireland (2006), BMZ (2009, 2011), DFID (2011), J ICA (2011), AusAID (2012), European Commission (2012), W orld Bank (2012) 
